\title{
The economics of low pressure drip irrigation and hand watering for vegetable production in the Sahel
}

\author{
Lennart Woltering*, Ali Ibrahim, Dov Pasternak, Jupiter Ndjeunga \\ International Crops Research Institute for the Semi-Arid Tropics (ICRISAT), P.O. Box 12404, Niamey, Niger
}

\section{A R T I C L E I N F O}

\section{Article history:}

Received 21 February 2011

Accepted 25 July 2011

\section{Keywords:}

Smallholder producers

African Market Garden

Drip irrigation

Labor use

Returns on investment

Water application efficiency

\begin{abstract}
A B S T R A C T
Low pressure drip irrigation is being promoted in Sub Saharan Africa as an alternative to traditional methods of small scale irrigation of vegetables. The African Market Garden (AMG) is a horticultural production system for smallholders based on low-pressure drip irrigation combined with an improved crop management package. The agronomic and economic performance of the AMG is compared to two gardens irrigated manually with watering cans. One of these gardens is managed according to the same improved crop management package as in the AMG, this treatment is called Improved Management (IM). The other garden is managed according to common practices of vegetable producers in the area, this treatment is called the Farmer Practice (FP). Crop productivity, labor and water use were monitored for two vegetable species (okra and eggplants). The experiment was performed on-station in Niger on three adjacent $500 \mathrm{~m}^{2}$ plots in a sandy acid soil. It was found that improved crop management practices greatly enhance crop productivity over traditional methods at comparable production costs. The AMG gave higher crop yields and higher returns to investment than the treatments irrigated with watering cans. Labor accounts for up to $45 \%$ of the production cost in vegetable gardens irrigated by hand, where $80 \%$ of the producer time is spent on irrigation. The total labor requirement for the drip irrigated AMG was on average 1.1 man hours per day against 4.7 man hours per day for the Farmers Practice on a $500 \mathrm{~m}^{2}$ garden. Returns on labor are at least double for the AMG against the other treatments. The returns on land from eggplant were found to be US\$1.7, 0.8 and 0.1 per $\mathrm{m}^{2}$ for the AMG, IM and FP respectively. The returns on water for the cultivation of eggplant are around US\$2 per $\mathrm{m}^{3}$ in the AMG, against US\$0.1 in the Farmers Practice. This experiment showed the strong positive impact of drip irrigation and improved crop management practices on profits at minimal environmental costs, indicating that transformation of existing practices poses a considerable potential towards sustainable agricultural development.
\end{abstract}

(c) 2011 Elsevier B.V. All rights reserved.

\section{Introduction}

Irrigated horticultural production is a major source of income and employment for millions of smallholder producers in Sub Saharan Africa (Weinberger and Lumpkin, 2005). These smallholder producers generally cultivate vegetables on $0.01-0.50$ ha gardens using traditional practices for crop husbandry, fertility management and irrigation. An estimated $80 \%$ of gardens in West Africa are still irrigated by hand using watering cans, buckets or calabash (Drechsel et al., 2006; Dittoh et al., 2010). This method is labor intensive and about half of the water applied to the field is lost to surface runoff due to high irrigation intensity, evapora-

\footnotetext{
* Corresponding author. Current address: GFA Consulting Group GmbH, Eulenkrugstrasse 82, D-22359 Hamburg, Germany. Tel.: +49 4060306 356; fax: +494060306119 .

E-mail addresses: LennartWoltering@yahoo.com (L. Woltering), i.ali@cgiar.org (A. Ibrahim), dovp@bgu.ac.il (D. Pasternak), j.ndjeunga@cgiar.org (J. Ndjeunga).
}

tion and deep percolation (Batchelor et al., 1996). Drip irrigation has been in use since the 1960s to improve agricultural water productivity, creating more output (in physical and economic terms) with less water. Yet little is known about the actual benefits of this technology when applied by smallholder producers in Africa.

Drip irrigation delivers water directly to the root zone of the crop through a network of pipes, emitters and control valves. This minimizes conveyance losses and allows for uniform distribution of water over the field at regular time intervals. Besides that, irrigation water can easily be mixed with soluble fertilizer (called fertigation). As a result, drip irrigation has been found to increase both yield and water saving by about $50 \%$ over other irrigation techniques (Sivanappan, 1994). This can make the investment in a drip irrigation system economically viable compensating for the high capital cost for the drip equipment (Dhawan, 2000). These studies have focused on conventional drip irrigation systems that are used on large farms and require pumps to bring the pressure to a minimum of 2 bars. These systems are too expensive and sophisticated 
Table 1

Water application, fertility and crop management per treatment and crop.

\begin{tabular}{|c|c|c|c|c|}
\hline & \multirow[t]{2}{*}{ AMG } & \multirow[t]{2}{*}{ IM } & \multicolumn{2}{|l|}{ FP } \\
\hline & & & Okra & Eggplant \\
\hline Irrigation method & Drip & Watering can & Watering can & Watering can \\
\hline Irrigation intensity $\left(\mathrm{mm} \mathrm{h}^{-1}\right)$ & $1.7^{\mathrm{a}}$ & 300 & 300 & 300 \\
\hline Water applied (mm day $\left.{ }^{-1}\right)$ & 8 & 8 & 10 & 10 \\
\hline Manure $\left(\mathrm{kg} \mathrm{m}^{-2}\right)$ & 4 & 4 & 3.2 & 1 \\
\hline $\mathrm{NPK}^{\mathrm{b}}\left(\mathrm{kg} \mathrm{m}^{-2}\right)$ & 0.1 & 0.1 & 0 & 0.01 \\
\hline Urea $\left(\mathrm{kg} \mathrm{plot}^{-1}\right)$ & $42-52^{c}$ & & 15 & 25 \\
\hline Planting density (cm) & $100 \times 60$ & & $50 \times 50$ & $50 \times 50$ \\
\hline
\end{tabular}

a At lateral spacing $1 \mathrm{~m}$ there are 3.3 emitters per $\mathrm{m}^{2}$ at $0.5 \mathrm{Lh}^{-1}$ emitter $^{-1}$ giving $1.7 \mathrm{~mm} \mathrm{~h}^{-1}$.

b Commercial fertilizer (15-15-15) containing $15 \% \mathrm{~N}, 6.5 \% \mathrm{P}$ and $12.4 \% \mathrm{~K}$.

c Urea was applied at $0.8 \mathrm{~g} \mathrm{~m}^{-2} \mathrm{day}^{-1} ; 42 \mathrm{~kg}$ and $52 \mathrm{~kg}$ of urea were applied per plot of $500 \mathrm{~m}^{2}$ for okra and eggplant respectively.

for smallholder producers in developing countries (Cornish, 1998). Low pressure drip systems use only the pressure of slightly elevated water holding structures to irrigate small areas. The design is simple and it can be easily operated by less educated producers (Hillel, 1989). Small affordable kits serving $10-120 \mathrm{~m}^{2}$ have been widely promoted to smallholder producers in Africa and Asia (Postel et al., 2001). However, Maisiri et al. (2005) found in Zimbabwe no significant yield increase, labor saving or other economic advantage of using a $100 \mathrm{~m}^{2}$ drip kit over conventional surface irrigation. Several studies (Kabutha et al., 2000; ITC, 2003; Moyo et al., 2006) found that small drip kits serving up to $120 \mathrm{~m}^{2}$ did not show any significant saving in labor as compared with applying water directly to the field, resulting in large scale dis-adoption of the small drip kits by producers. Labor saving is very important for producers, because labor is a major production cost (Perry, 1997). Reduction in labor allows the cultivation of larger plots or allows for more time in favor of other income generating tasks, which is especially important for women producers (Burney et al., 2010). The few studies performed in Africa concluded that the introduction of low pressure drip irrigation should be complementary to technical, agronomic and marketing support to achieve improved returns from vegetable production (ITC, 2003; Kulecho and Weatherhead, 2006; Belder et al., 2007).

Since 2001, the International Crops Research Institute for the Semi-Arid Tropics (ICRISAT) in Niger and partners invested in the development of an integrated horticultural production system called the African Market Garden (AMG) (Pasternak and Bustan, 2003; Woltering et al., 2011). The AMG combines low-pressure drip irrigation with improved crop management. The latter helps the producer to apply the right amount of water, use suitable vegetable varieties for year round production, and improve soil fertility, among others. Woltering et al. (2011) describe the importance of economies of scale in low pressure drip irrigation and advocate for minimal garden sizes of $500 \mathrm{~m}^{2}$. The current study compared the returns to investment on the African Market Garden (AMG), and watering can irrigation methods for vegetable production in Niger. The specific objectives of this experiment were to determine labor and other production costs and water use of the AMG and the local hand watering vegetable production system. In addition, the performance of the improved crop husbandry package was compared in combination with drip irrigation (AMG) and with hand watering (IM).

\section{Methodology}

\subsection{Experimental site}

The experiment was conducted at the ICRISAT Sadore research station in Niger $\left(13^{\circ} 15^{\prime} \mathrm{N}, 2^{\circ} 17^{\prime} \mathrm{E}\right), 30 \mathrm{~km}$ southeast of the capital Niamey. The soil is classified as a sandy silicious isohyperthemic
Psammentic Paleustalf (West et al., 1984). It belongs to the Labucheri type characterized by a high sand content, low native fertility with low organic matter and low cation exchange capacity that limits nutrient storage ability. These soils are generally very strongly acidic, and aluminium comprises a high percentage of the exchangeable cations. The quantity of water held between 0.1 bar ("field capacity") and 15 bar ("permanent wilting point") soil moisture tension is around $0.2 \mathrm{~g} \mathrm{~cm}^{-3}$. Average annual rainfall is $560 \mathrm{~mm}$ that normally falls between June and October.

\subsection{Experimental set-up and management}

Two irrigation methods were used in combination with two crop husbandry practices for the cultivation of okra (Abelmoschus esculentus) and eggplant (Solanum melongena). Three $500 \mathrm{~m}^{2}$ fields $(20 \mathrm{~m} \times 25 \mathrm{~m})$ with ten raised $(0.2 \mathrm{~m})$ planting beds each were prepared. The planting beds were $25 \mathrm{~m}$ long and $1.8 \mathrm{~m}$ wide, separated by a $0.2 \mathrm{~m}$ path. For the treatments irrigated with watering cans there was a $0.5 \mathrm{~m}$ path every $8 \mathrm{~m}$ across the bed, and earthen borders were used that prevented any runoff spilling over to other beds. Two different vegetables were grown at the same time each on five beds. The two outer beds were considered borders and not included in the analysis. Each field was considered a treatment, with each planting bed a replication in a randomized complete block design. The order of planting beds was then kept equal for the treatments (Fig. 1). The treatments are summarized in Table 1 and defined as follows:

1. African Market Garden (AMG): Improved crop husbandry package and irrigation with low pressure drip irrigation. Drip laterals were $12 \mathrm{~mm}$ in diameter with in line drip emitters spaced at $0.30 \mathrm{~m}$ interval. Drip emitter discharge was $0.4-0.5 \mathrm{~L} / \mathrm{h}$. Distance between the laterals on the planting bed was $1 \mathrm{~m}$ for both okra and eggplants. The water was collected in a $4 \mathrm{~m}^{3}$ reservoir and was gravity fed to the plot at a pressure varying between 2.5 and $1 \mathrm{~m}$ head (drip emitter discharge $0.4-0.5 \mathrm{~L} / \mathrm{h}$ ). The reservoir provides $8 \mathrm{~mm} \mathrm{(} 4 \mathrm{~m}^{3}$ for $500 \mathrm{~m}^{2}$ ) of irrigation, corresponding to local maximum crop daily evapotranspiration rates (Pasternak et al., 2006). Planting beds were prepared with a basic dressing of $4 \mathrm{~kg} \mathrm{~m}^{-2}$ manure and $0.1 \mathrm{~kg} \mathrm{~m}^{-2}$ of a complete fertilizer called $15-15-15$ containing $15 \% \mathrm{~N}, 6.5 \% \mathrm{P}$ and $12.4 \% \mathrm{~K}$ before planting. Urea was mixed daily with the water in the reservoir to give a concentration of $50 \mathrm{ppm} \mathrm{N}$ in the irrigation water. Crops were irrigated by hand for the first 3 days after planting at $4 \mathrm{~mm}$ day $^{-1}$. Planting density was according to extension service guidelines.

2. Improved Management (IM): Improved crop husbandry package but irrigation with watering cans. The quantity of water 
Farmer Practice (FP)

o $2 \mathrm{~m}^{3}$ water basin

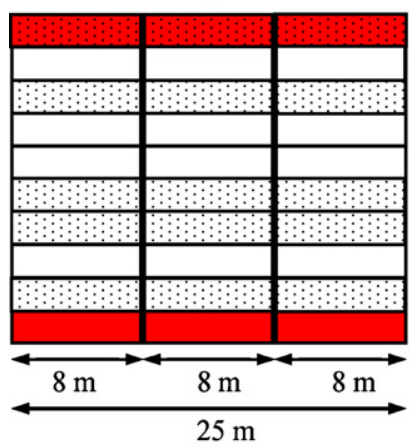

Improved Management (IM)

○ $2 \mathrm{~m}^{3}$ water basin

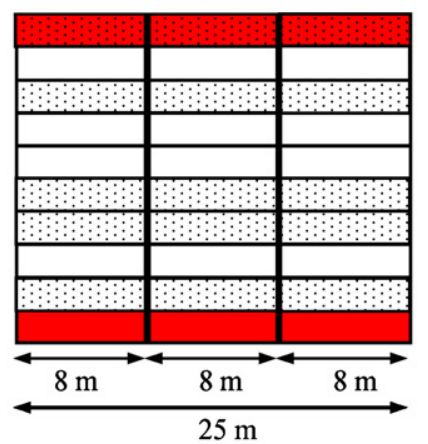

African Market Garden (AMG)

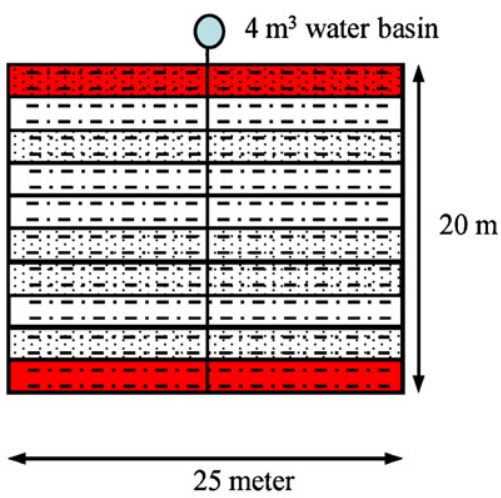

Planting beds:

crop 1

crop 2

border

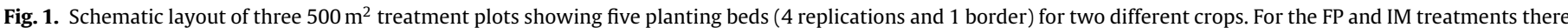
are walking paths for water delivery from the water basins.

applied, the preparation of planting beds and the planting density were similar to the AMG treatment. However, water was applied by watering cans two times per day; two thirds in the morning $(5.3 \mathrm{~mm})$ and one third in the afternoon $(2.7 \mathrm{~mm})$. Two watering cans of $12 \mathrm{~L}$ each were emptied over the planting beds at an intensity of about $300 \mathrm{~mm} \mathrm{~h}^{-1}$. The total amount of urea applied per crop was equal to the quantity applied for the AMG, but it was applied through broadcasting and only twice during crop development; half was applied 21 days after planting and the other half at flowering.

3. Farmer Practice (FP): Local crop husbandry practices and irrigation with watering cans. Information on water application regime, fertilizer use, planting density and other variables was collected through surveys in and around Niamey city. Eighteen okra producers, fourteen eggplant producers, and five horticulture extension specialists were interviewed. On average, vegetable producers apply $10 \mathrm{~mm} \mathrm{day}^{-1}$ for okra and eggplant (Table 1). Manure and urea were applied at the first grubbing, about three weeks after planting, and at flowering stage. The manure was applied on the soil surface without incorporation into the soil.

It should be noted that in the AMG and IM treatments a standard amount of $8 \mathrm{~mm}$ of irrigation (based on local maximum crop daily evapotranspiration rates) was applied daily irrespective of the crop or the season. The standard size of the reservoir is $4 \mathrm{~m}^{3}$ and emptying it once will give $8 \mathrm{~mm}$ over a $500 \mathrm{~m}^{2}$ plot. This was found the best way to help farmers applying a rational amount of irrigation water (Pasternak et al., 2006). Even though surplus of water is applied for parts of the crop period, around $50 \%$ water is saved compared to irrigation quantities commonly applied by farmers around Niamey. Irrigation was suspended for one or two days when rainfall exceeded 20-40 mm day $^{-1}$.

Okra (var. Konni) and eggplant (var. Black Beauty) were selected for this experiment as these are popular vegetables for cultivation in Niamey (Mahamadou, 2005; Babatunde et al., 2007; Gowda et al., 2010). Okra was grown three times; in the rainy season of 2008 , in the dry season of 2008 going into 2009, and the 2009 rainy season. Eggplant was grown only once in the experiment; in the dry season 2008-2009.

\subsection{Data collection and analysis}

\subsubsection{Agronomic}

Fresh fruit yield was collected and weighed for each of the four replications (planting beds) per treatment. Weeds were collected, dried and weighed for the three treatments. Individual fruit weight, days to first and 50\% flowering, days to $50 \%$ maturity and total dry matter were recorded for okra (only rainy season 2009) and eggplant. The crops were regularly inspected for signs of disease, pests or viruses, and traces of insect attacks. Pest management experts inspected the plots about once per month and took leaf or root samples for laboratory analysis in case of incidents. The quantity and type of chemicals required to keep pests and diseases to a minimum were recorded per treatment. Presence of nematodes in the soil was measured in March 2009. The physical and chemical status of the soil was analyzed at $0-10,10-20$ and $20-40 \mathrm{~cm}$ depth, before the start of the experiment in June 2008 and in September 2009. Evaporation was measured from a Class-A USWB evaporation pan at a meteorological station about $500 \mathrm{~m}$ from the experimental plots.

\subsubsection{Economics}

Labor time per person expressed in man hour (m.h.), was recorded per activity starting at the installation of the gardens and continuing to the operational activities such as planting, irrigation and weeding ending with harvesting. Labor cost was set at US\$ 2 per man-day (field data; World Bank, 2008). Gross revenues were calculated at $60 \%$ of the consumer price of vegetables over the actual harvest period (data SIMA-System d'Information sur les Marches Agricoles and INS-Institut National de Statistique). Data on crop yield, input use and labor collected in this on-station experiment were complemented with data collected in farmers' fields on investment, maintenance and other costs and market data. This allows calculations on returns on investment in a garden setting representative of vegetable producers in and around Niamey. The returns on land, labor and water, and payback period were calculated using amortization over the crop period, production costs and potential revenues at the time of harvest. The water application efficiency is defined as fresh fruit weight $(\mathrm{kg})$ obtained per unit volume of irrigation water applied $\left(\mathrm{m}^{3}\right)$.

All calculations were done based on a unit area of $500 \mathrm{~m}^{2}$, the standard size of the production unit in an AMG. Analysis of variance (ANOVA) was conducted to evaluate the effects of the treatments on fresh fruit yield $\left(\mathrm{kg} \mathrm{m}^{-2}\right)$ and dry weight of weeds 
Table 2

Fresh fruit yield and dry matter per season per treatment.

\begin{tabular}{|c|c|c|c|c|c|c|c|c|c|}
\hline \multirow[t]{2}{*}{ Crop } & \multirow[t]{2}{*}{ Season $^{\mathrm{a}}$} & \multicolumn{3}{|c|}{ Fresh Fruit yield } & \multirow[t]{2}{*}{$F$-prob } & \multicolumn{3}{|l|}{ Dry matter } & \multirow[t]{2}{*}{$F$-prob } \\
\hline & & AMG $\left(\mathrm{kg} \mathrm{m}^{-2}\right)$ & $\mathrm{IM}\left(\mathrm{kg} \mathrm{m}^{-2}\right)$ & $\overline{\mathrm{FP}}\left(\mathrm{kg} \mathrm{m}^{-2}\right)$ & & AMG $\left(\mathrm{kg} \mathrm{m}^{-2}\right)$ & $\mathrm{IM}\left(\mathrm{kg} \mathrm{m}^{-2}\right)$ & $\overline{\mathrm{FP}}\left(\mathrm{kg} \mathrm{m}^{-2}\right)$ & \\
\hline \multirow[t]{3}{*}{ Okra } & RS08 & 1.52 & 1.39 & 1.04 & $<.001$ & - & - & - & - \\
\hline & DS08/09 & 1.15 & 0.73 & 0.94 & 0.013 & - & - & - & - \\
\hline & RS09 & 1.94 & 1.39 & 0.47 & 0.002 & 0.87 & 0.41 & 0.39 & 0.002 \\
\hline Eggplant & DS08/09 & 6.15 & 4.09 & 2.54 & $<.001$ & 4.51 & 2.96 & 2.06 & 0.06 \\
\hline
\end{tabular}

a Season: RS08 signifies rainy season (June-October) 2008, DS08/09 signifies dry season (November-May) $2008-2009$.

(kg). The statistical package GenStat 10th Edition was used to calculate $F$ probabilities, and differences were considered significant at $P \leq 0.05$.

\section{Results and discussion}

\subsection{Yields and cultural attributes}

The fresh fruit yields of okra and eggplant grown in the AMG were significantly higher than those in the other treatments (Table 2).

Total dry matter of okra and eggplant in the AMG treatment was around double the dry matter yield in the other two treatments. This confirms the positive effect of drip irrigation on plant productivity. Rainy season fruit yield of okra in the IM treatment in the 2008 season was 33\% higher than that in the FP treatment and in the 2009 rainy season it was $300 \%$ higher. This could be attributed to a build up of soil fertility over time in the IM plot due to high rates of manure and NPK application. In the dry season high temperatures dominated crop yield and this might have been the reason for the little effect of the additional inputs in the IM treatment as compared with the FP system. Days to flowering and fruiting were similar across all treatments for eggplant, however individual fresh fruit weight was highest for AMG at $0.20 \mathrm{~kg}$ per fruit against 0.17 and $0.13 \mathrm{~kg}$ per fruit for IM and FP respectively. There was no noteworthy difference in signs of viruses or insect pressure over the treatments and over time observed. The practical implication of these findings is that farmers in Niger (and elsewhere in Africa) can significantly increase yields in their traditional gardening systems by increasing the amount of fertilizer and manure, decreasing planting density while at the same time using less water.

It was found that $45 \%$ less weeds were collected from the AMG compared with the two hand watered treatments. The total dry weight of weeds collected from $500 \mathrm{~m}^{2}$ over the experimental period was $16 \mathrm{~kg}$ for the AMG, $24 \mathrm{~kg}$ for the IM and $29 \mathrm{~kg}$ for the FP. Drip irrigation delivers water directly to the plant roots, thus leaving the space between plants dry. In contrast, watering cans wet the entire planting bed facilitating weed development. Most weeds were collected from the Farmers Practice (Fig. 2), probably due to higher water application, and two times application of manure (that contains a lot of weed seeds) on the surface.

\subsection{Economics}

\subsubsection{Labor use}

The total labor used in the drip irrigated garden was onefourth that of the two treatments that were irrigated with watering cans. Fig. 3 shows the labor used for the main activities; planting, irrigation, soil improvement (fertilization and planting bed preparations), weeding and grubbing, harvesting and phyto-sanitarian treatments as an average over the three crops. The total labor requirements in a $500 \mathrm{~m}^{2}$ garden are 1.1 man hours per day for the AMG against 4.4 and 4.7 man hours per day respectively for the IM and FP (Fig. 3). This difference can be mainly attributed to the high labor requirement for irrigation with watering cans. In

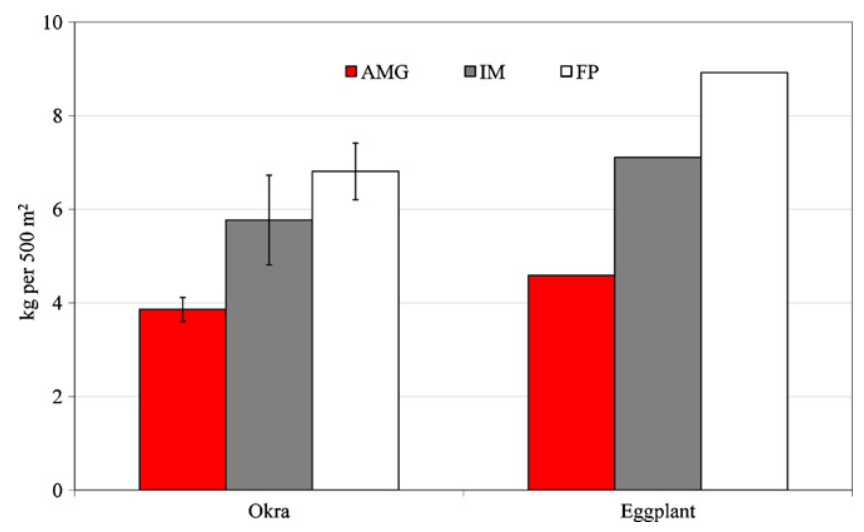

Fig. 2. Dry weight of weeds per crop in $\mathrm{kg}$ per $500 \mathrm{~m}^{2}$ and standard error.

the AMG, it takes about 10 min per day to clean the filter, open the valve and check the drippers for clogging, whereas it takes 4 man hours to irrigate $500 \mathrm{~m}^{2}$ with watering cans. The AMG and IM treatments require more labor for fertilization of the soil as planting beds are prepared with fertilizer and manure before planting, and regular mixing (in the case of drip irrigation) of soluble fertilizer in the water. From Fig. 3 it can be seen that about 30\% more labor was required in the Farmer Practice for weeding and grubbing, due to higher weed pressure as compared with the AMG and IM treatments (as was shown in Fig. 2). When using watering cans the labor requirement for cultivating irrigated crops will increase proportionally with area. This is not the case when using drip irrigation, doubling or even quadrupling the irrigated area will result in a small increase in labor for cultivation provided the volume of the reservoir increases proportionally with the area (Woltering et al., 2011). The comparative advantage of drip irrigation over hand watering is proportional to the labor that can be saved to irrigate the crop area. Hence, the larger the area the producer irrigates the more

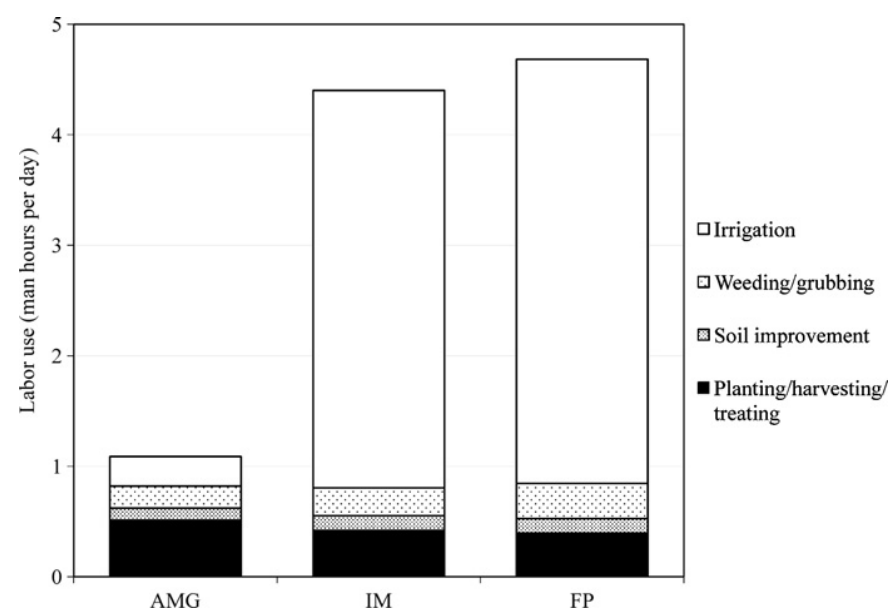

Fig. 3. Labor use per activity in man hours per day for a $500 \mathrm{~m}^{2}$ garden averaged over all crops per treatment. 
Table 3

Total evaporation, rainfall and irrigation quantities per crop over the dry and rainy season.

\begin{tabular}{|c|c|c|c|c|c|c|c|}
\hline & \multirow[t]{2}{*}{ Days } & \multirow[t]{2}{*}{$\mathrm{PET}^{\mathrm{a}}(\mathrm{mm})$} & \multirow[t]{2}{*}{ Rainfall (mm) } & \multicolumn{2}{|l|}{ AMG and IM } & \multicolumn{2}{|l|}{ FP } \\
\hline & & & & Irrigation (mm) & Total water to $\operatorname{crop}^{\mathrm{b}}(\mathrm{mm})$ & Irrigation $(\mathrm{mm})$ & Total water to crop (mm) \\
\hline Okra RS08 & 105 & 380 & 437 & 716 & 1153 & 920 & 1357 \\
\hline Okra DS08/09 & 105 & 778 & 139 & 840 & 979 & 1050 & 1189 \\
\hline Okra RS09 & 109 & 433 & 342 & 672 & 1014 & 840 & 1182 \\
\hline Eggplant DS08/09 & 120 & 814 & 83 & 840 & 923 & 1050 & 1133 \\
\hline
\end{tabular}

a PET, potential evapotranspiration, defined as $0.8 \times$ pan evaporation.

b Irrigation + rainfall.

Table 4

Water application efficiency $\left(\mathrm{kg} \mathrm{m}^{-3}\right)$ for okra and eggplant in three production systems.

\begin{tabular}{lllll}
\hline Crop & Season $^{\mathrm{a}}$ & AMG $\left(\mathrm{kg} \mathrm{m}^{-3}\right)$ & $\mathrm{IM}\left(\mathrm{kg} \mathrm{m}^{-3}\right)$ & $\mathrm{FP}\left(\mathrm{kg} \mathrm{m}^{-3}\right)$ \\
\hline Okra & RS08 & 2.12 & 2.03 & 1.18 \\
& DS08/09 & 1.37 & 0.87 & 0.90 \\
\multirow{2}{*}{ Eggplant } & RS09 & 2.89 & 2.06 & 0.56 \\
\hline
\end{tabular}

a Season: RS08 signifies rainy season 2008, DS09 signifies dry season 2009.

benefits he/she will get from drip irrigation. It should be noted that savings in hired labor can become socially problematic if no alternative livelihood opportunities exist in the community. On the other hand, on farm employment can be compensated when the saved water is used to expand the irrigated area, or through crop intensification. Laborers will experience an improvement in quality of employment as the drudgery of carrying heavy water containers is minimized under drip irrigation.

\subsubsection{Water application efficiency}

In the AMG and IM treatments a standard quantity of $8 \mathrm{~mm}$ of irrigation was applied daily irrespective of the crop or the season. From field surveys it was found that farmers commonly apply $25 \%$ more water for eggplant and okra. Table 3 shows the total potential evapotranspiration, rainfall and irrigation water applied for each crop in the different seasons.

The same amount of water was applied to the AMG and IM treatments, but more fruit and dry matter yield was produced under the AMG treatment. For each cubic meter of water applied the AMG yielded $7.3 \mathrm{~kg}$ of eggplant, against $4.9 \mathrm{~kg}$ for the IM and only 2.4 for the FP (Table 4). The water application efficiency was generally found to be more than 2 times higher for the AMG and IM treatments than for the Farmer Practice.
Table 5

Set-up cost of $500 \mathrm{~m}^{2}$ garden equipped with AMG drip or watering cans.

\begin{tabular}{lcc}
\hline & AMG drip (US\$) & Watering can (US\$) \\
\hline Drip hardware $500 \mathrm{~m}^{2}$ & 371 & 0 \\
Reservoir & 400 & 100 \\
Pump and connections & 420 & 420 \\
Well & 160 & 160 \\
Fence & 104 & 104 \\
Tools & 110 & 140 \\
Total & 1565 & 924 \\
Amortized value & 264 & 214 \\
Monthly equivalent & 22.01 & 17.87 \\
\hline
\end{tabular}

\subsubsection{Set-up cost}

Irrigated vegetable production is a capital intensive undertaking of which the drip hardware and reservoir constitute less than $50 \%$ of the total set-up costs. Depending on site specifics, producers that want to set up a vegetable garden, will have to invest in a pump, well, reservoir and water distribution system, as well as in tools and a fence. Table 5 shows the set-up costs for a $500 \mathrm{~m}^{2}$ garden using the AMG and watering cans for irrigation.

It can be seen that, getting the water to the reservoir, purchasing tools and protecting the garden with a fence require an investment of around US\$ 800 irrespective if a vegetable producer uses watering cans or drip irrigation. The AMG "commercial model" of $500 \mathrm{~m}^{2}$ used in this experiment requires an additional US\$ 771 for a cylindrical concrete reservoir and a drip system. But in other models developed by ICRISAT (Woltering et al., 2011), where water is supplied centrally to a large number of $500 \mathrm{~m}^{2}$ units, the relative cost of the water reservoir per production unit is much smaller.

\subsubsection{Return to investment}

Table 6 shows the major production costs and amortization, revenues and returns for the crops grown in the three treatments.

The production cost for the AMG were on average 30\% lower than that for the treatments irrigated with watering cans. Cost for

Table 6

Crop budget and returns to land, labor and water.

\begin{tabular}{|c|c|c|c|c|c|c|}
\hline & \multicolumn{3}{|c|}{ Okra (106 days) } & \multicolumn{3}{|c|}{ Eggplant (120 days) } \\
\hline & AMG (US\$) & IM (US\$) & FP(US\$) & AMG (US\$) & IM (US\$) & FP (US\$) \\
\hline Farm inputs & 93 & 93 & 58 & 91 & 91 & 71 \\
\hline Maintenance & 24 & 24 & 24 & 27 & 27 & 27 \\
\hline Fuel & 60 & 60 & 75 & 68 & 68 & 84 \\
\hline Labor & 41 & 133 & 138 & 34 & 139 & 153 \\
\hline Production cost & 218 & 310 & 295 & 220 & 325 & 336 \\
\hline Amortization & 77 & 63 & 63 & 88 & 71 & 71 \\
\hline Total cost & 295 & 373 & 357 & 308 & 397 & 407 \\
\hline Revenues & 595 & 451 & 337 & 1163 & 775 & 481 \\
\hline Net benefit & 301 & 78 & -20 & 855 & 378 & 74 \\
\hline Returns on land & 0.6 & 0.2 & 0.0 & 1.7 & 0.8 & 0.1 \\
\hline Returns on labor & 2.4 & 0.1 & 0.0 & 6.3 & 0.7 & 0.1 \\
\hline Returns on water & 0.8 & 0.2 & -0.1 & 2.0 & 0.9 & 0.1 \\
\hline
\end{tabular}


farm inputs were higher, but this was largely compensated by savings of up to $50 \%$ in water (fuel cost) (Table 3 ) and a 4 -fold savings in labor when using drip irrigation (Fig. 3). Energy is a major production cost (65\%) when irrigating with watering cans, at $45 \%$ for human energy (labor) and 20\% for pumping energy. Okra and eggplant production was profitable for the AMG but gave negligible returns for the Farmer Practice. The low profitability of okra in this trial resulted from the fact that okra was produced mostly in the rainy season when prices for this product are low. Okra produced in other seasons fetch much higher prices resulting in higher profits. The returns on land for eggplant for the AMG were double that of the IM at US\$ 1.7 against US\$ 0.8 per $\mathrm{m}^{2}$ land. The IM treatment showed a great improvement over the Farmer Practice at similar costs but at much higher revenues for most crops. Returns on labor were at least double for the AMG drip irrigation treatment against the other treatments. The returns on water in the AMG were around US\$ 2 for production of eggplant. In the FP returns on water were found insignificant (US\$ -0.1 and 0.1 per $\mathrm{m}^{3}$ ) for okra and eggplant.

Most publications describing the advantages of drip irrigation over other systems emphasize the effect of water saving and higher yields resulting in higher water use efficiency (Bresler, 1975; Sivanappan, 1994; Postel et al., 2001). However for Africa's horticulture producers labor saving is by far the most important advantage of drip irrigation.

\section{Conclusions}

The AMG technology holds great promise to increase profitability of smallholder vegetable producers as it combines drip irrigation and improved crop management. The results of this study contributed to a better understanding of the advantages and disadvantages of the AMG, and the drip technology in general, and are of interest to farmers, development agencies and decision makers that focus on income generation and improved nutrition in West Africa. Drip irrigation saves labor, water and energy, bringing down production costs, but by far the major advantage of drip irrigation when substituting traditional systems is labor saving. As labor constitutes around $45 \%$ of the production costs in hand watered gardens, the vital comparative advantage of drip irrigation over hand watering is proportional to the labor that can be saved to irrigate the crop area. Hence, the larger the area the producer irrigates the more benefits he/she will get from drip irrigation. The lower labor requirement markedly increases the returns on labor that can be six times higher than in the traditional system. This is a very important contribution to poverty alleviation. However, it should be noted that alternative employment opportunities for laid-off workers should be available in the communities. Improved crop management significantly increases yields mostly through a considerable addition of organic and inorganic fertilizers. Thus by application of proper rates of fertilizers, and the timing of fertilizer application, traditional vegetable producers can easily improve productivity without having to invest in a new irrigation technology. The high investment cost for drip irrigation equipment is one of the major limitations for uptake of the technology. The instinctive solution to decrease the size of the drip irrigated garden and thereby limiting the investment has proved to be counterproductive as drip irrigation will lose its biggest comparative advantage (reduced operational expenses due to labor saving) over traditional methods of irrigation. It is recommended to replicate this experiment in farmers' fields over diverse agroecological zones in the Sudano-Sahel. The technologies combined in the AMG can reduce pressure on natural resources and reduce land degradation while improving the livelihoods of smallholder producers.

\section{Acknowledgements}

The authors would like to thank the following people and institutes. Ms Saadaatou Oumarou (student IPR/IFRA de Katibougou, Mali) for assisting in setting up the experiment and the monitoring routine. Dr Alain Ratnadass (CIRAD), Dr Patrice Cadet (Institut de Recherche et Développement) and Mr Adamou Mounkaila for taking root and soil samples for analysis of nematodes and monitoring insect and disease activity in the field. Dr Sanjeet Kumar (AVRDC The World Vegetable Center) and Mr Issaka Housseini for their regular field visits and discussions on observations. This research was funded by ICRISAT with a contribution from the Taiwan government through the AMIV (Affordable Micro Irrigation for Vegetables) project.

\section{References}

Babatunde, R.O., Omotesho, A.O., Olorunsanya, E.O., Amadou, A., 2007. Optimal crop combination in small-scale vegetable irrigation farming scheme: case study from Niger republic. Research Journal of Applied Sciences 2 (5), 617-622.

Batchelor, C., Lovell, C., Murata, M., 1996. Simple microirrigation techniques for improving irrigation efficiency on vegetable gardens. Agricultural Water Management 32, 37-48.

Belder, P., Senzanje, A., Manzungu, E., Twomlow, S., Rohrbach, D., 2007. Can drip irrigation improve livelihood of smallholders? Lessons learned from Zimbabwe. Paper presented at SADC Symposium on Land and Water management, 19-23 February, Gaborone, Botswana (sub theme 4: pp. 245-256).

Bresler, E., 1975. Trickle-drip irrigation principles and applications to soil water management. Advances in Agronomy 29, 343-393.

Burney, J., Woltering, L., Burke, M., Naylor, R., Pasternak, D., 2010. Solar-powered Drip Irrigation Enhances Food Security in the Sudano-Sahel. Proceedings of the National Academy of Sciences 107 (5), 1848-1853.

Cornish, G.A., 1998. Pressurised irrigation technologies for smallholders in developing countries - a review. Irrigation and Drainage Systems 12, 185-201.

Dhawan, B., 2000. Drip irrigation: evaluating returns. Economic and Political Weekly (India), 3775-3780, October 14

Dittoh, S., Issaka, B.Y., Akuriba, M.A., Nyarko, G., 2010. Extent of use and impacts of affordable micro-irrigation for vegetables (AMIV) technologies in five countries in West Africa. Final research report to AVRDC - The World Vegetable Center, University for Development Studies, Tamale, Ghana.

Drechsel, P., Graefe, S., Sonou, M., Cofie, O., 2006. Informal irrigation in urban West Africa: an overview. IWMI Research Report 102, International Water Management Institute, Colombo, Sri Lanka, 40 pp. http://www.iwmi.cgiar.org/pubs/ pub102/RR102.pdf.

Gowda, C.L.L., Pasternak, D., Kumar, S., Nikiema, A., Woltering, L., 2010. Crop diversification with horticultural crops for enhancing incomes and improving livelihoods of poor farmers in dryland areas. In: Nath, P., Gaddagimath, P.B. (Eds.), Horticulture and Livelihood Security. Scientific Publishers, Rajasthan, India, pp. 269-279.

Hillel, D., 1989. Adaptation of modern methods to research priorities of developing countries. In: Le Moigne, G., Barghuti, S., Plusquellei, H. (Eds.), Technological and Institutional Innovation in Irrigation, World Bank Technical Paper No. 94, pp. 83-93.

ITC, 2003. Low-cost micro irrigation technologies for the poor. Final report to the UK Department for International Department, Knowledge and Research Programme (KAR) Project R7392, Intermediate Technology Consultants, Rugby, UK.

Kabutha, C., Blank, H., Van Koppen, B., 2000. Drip kits for smallholders in Kenya: experience and a way forward. In: Proceedings of the 6th International MicroIrrigation Congress on Micro-irrigation Technology for Developing Agriculture, 22-27 October 2000, Cape Town, South Africa, 7 pp.

Kulecho, I.K., Weatherhead, E.K., 2006. Adoption and experience of low-cost drip irrigation in Kenya. Irrigation and Drainage 55 (4), 435-444.

Mahamadou, O.A., 2005. Diffusion des systèmes d'irrigation goutte-à-goutte dans la zone péri-urbaine de Niamey et dans la région de Dosso au Niger. Mémoire de Fin d'études l'Institut de formation et de Recherche appliquée IPR/IFRA de Katibougou, Mali.

Maisiri, N., Senzanje, A., Rockstrom, J., Twomlow, S.J., 2005. On farm evaluation of the effect of low cost drip irrigation on water and crop productivity compared to conventional surface irrigation system. Physics and Chemistry of the Earth 30, 783-791.

Moyo, R., Love, D., Mul, M., Mupangwa, W., Twomlow, S., 2006. Impact and sustainability of low-head drip irrigation kits, in the semi-arid Gwanda and Beitbridge Districts, Mzingwane Catchment, Limpopo Basin, Zimbabwe. Physics and Chemistry of the Earth 31, 885-892, doi:10.1016/j.pce.2006.08.020.

Pasternak, D., Bustan, A., 2003. The African Market Garden. In: Stewart, B.A., Howell, T. (Eds.), Encyclopedia of Water Science. Marcel Dekker Inc., NY, pp. 9-15.

Pasternak, D., Nikiema, A., Senbeto, D., Dougbedji, F., Woltering, L., 2006. Intensification and improvement of market gardening in the Sudano-Sahel region of Africa. Chronica Horticulturae (ISHS) 46 (4), 24-28. 
Perry, E., 1997. Low-cost irrigation technologies for food security in Sub-Saharan Africa. In: Irrigation Technology Transfer in Support of Food Security. Proceedings of a Subregional Workshop, Harare, Zimbabwe, 14-17 April 1997, FAO Water Reports-14, FAO, Rome.

Postel, S.L., Polak, P., Gonzales, F., Keller, J., 2001. Drip irrigation for small farmers. A new initiative to alleviate hunger and poverty. Water International 26(1), 3-13.

Sivanappan, R.K., 1994. Prospects of micro-irrigation in India. Irrigation and Drainage Systems 8 (1), 49-58.

Weinberger, K., Lumpkin, T.A., 2005. Horticulture for poverty alleviation - the unfunded revolution. AVRDC Publication No. 05-613, Working Paper No. 15, AVRDC - The World Vegetable Center, Shanhua, Taiwan, p. 20.
West, L.T. Wilding L.P., Landeck, J.K., Calhoun, F.G., 1984. Soil Survey of the ICRISAT Sahelian Center, Niger, West Africa. Soil and Crop Sciences Department/Trop. Soils, The Texas A\&M University System College Station, Texas and International Crops Research Institute for the Semi-Arid Tropics.

Woltering, L., Pasternak, D., Ndjeunga, J., 2011. The African Market Garden: development of a low-pressure drip irrigation system for smallholder producers in the Sudano-Sahel. Irrigation and Drainage Online, doi:10.1002/ird.610.

World Bank, 2008. Developpement de l'irrigation au Niger: Diagnosti et Options Strategiques. Revue Sectorielle de l'Irrigation, Juin 2008. Agriculture et Developpement Rural, AFTAR 